\section{$1 \mathrm{P089}$}

\section{非天然状態にある蛋白質の部分分子容予測法の開発}

○関 安孝、曽田邦同（長岡技科大・生物）

部分分子容は，天然状態だけでなく，解鎖状態や变性中間状態など の非天然状態の蛋白質とその水和水の構造を反映する観測量である。 これらの実測值に基づいて, 多様な非天然状態にある蛋白質の構造を 議論できるためには，任意のコンホメーションをもつ蛋白質の部分分 子容に対する水和水の寄与を正確に予測する必要がある。これ迄に も，部分分子容に対して様々な予测法が提案されているが，任意のコ ンホメーションを持つ蛋白質の部分分子容を定量的に予測できる方法 は未だ無い。本研究の目的は，天然及び非天然状態の蛋白質に適用可 能な部分分子容の予測法を開発することである。

最初に，溶質と溶媒の間に水素結合が無いときの，溶質周辺の溶媒 水の空間分布を調べるために, メタンと部分電荷をぜロにした無極 性アラニン, リソチーム水溶液の分子動力学シミュレーションを行っ た。その結果，溶質分子表面近傍の “溶啠と溶媒の隙間”が部分分子 容に有意に奇与すること, またその厚さを分子表面で平均すると, 溶 質のサイズや表面形状に依存せず，約 $0.06 \mathrm{~nm}$ となることが分かった。 この隙間の寄与は，解鎖状態など分子表面積が大きい場合に，特に大 きくなる。次に，20種のトリペプチドと 4 種の蛋白質の分子動力学シ ミュレーションを行い，溶質と溶媒水分子との水素結合数を調べた。 その結果, 各水素結合サイトの平均水菜結合数は, 露出表面秸よりも 分子表面皘に良く比例することが分かった。予測法にこれらの結果を 取り込むことにより，溶媒簬出度が大きく異なる分子種（蛋白貿，ア ミノ酸、ジペプチド，有機低分子）について，夷測值を高精度で予測 することが可能になった。年会では，解鎖状態や変性中間状態等の非 天然状態の様々なモデルについて，予測結果を議論する。

Y.Seki, K.Soda : Developing a method for predicting the partial molecular volume of proteins in nonnative states

\section{$1 P 091$}

高酸化活性セレン試薬を用いたリボヌクレアーゼ A のフォールディング過程の解析

○米田 光政、逸見 佳代、岩岡 道夫 (東海大・理・化学)

SS 結合をもつタンパク質の酸化的リフォールディングの実験におい て、従来からグルタチオンやDTTox 等のイオウ試薬が用いられてき た。このようなイオウのリフォールディング試剤では、タンパク質と 平衡反応となるために多量の試薬が必要であり、かつ反応速度が遅い という欠点がある。しかし、最近DHSox と乎ばれる水溶性セレン試 薬が合成され、これを用いるとイオウ試薬よりもはるかに速く SS 結 合が生成することがわかった。リフォールディング中閒体では、SS 形 成反応と同時に SS 交换反応も進行することが考えられるが、DHSox を用いた場合には、SS 形成反応の方が速やかに進行するため、SS 交 換反応が起こる前に反応が完結する。即ち、DHSoxを用いることに より、SS 交換反応を分離することが可能である。本研究では、イオ ウの代わりにセレンを含む新しいフォールティング試剤の開発を進 め、それらを用いたリボヌクレアーぜ Aのリフォールディンク過程の 解析を行い、セレン試楽の有用性を示すことを目的に研究を行った。 DHSox を用いたリボヌクレアーぜ A のリフォールディング実験では、 HPLC の解析からフォールディング過程が $\mathrm{R} \rightarrow 1 \mathrm{~S} \rightarrow 2 \mathrm{~S} \rightarrow 3 \mathrm{~S} \rightarrow 4 \mathrm{~S}$ となることがわかった。実験テータの解析から反応速度定数 $(\mathrm{k} 1-$ k4）を求めたところ、速度定数の值は中間体に含まれる SH 基の数に ほぼ比例することがわかった。SS 形成反忘が迅速かつ不可逆である ことを利用して、SS 交換反応をモニターしたところ、3S 中間体から 熱力学的に安定な N 体 (native 状態)の生成が最終的に確認できた。

M. Yoneda, K. Henmi and M. Iwaoka : Analysis of the folding pathways of ribonulease $A$ by using selenium reagents with high oxidizing ability.

\section{$1 P 090$}

シトクロムcのモルテングロビュール状態の多状態熱 転移に伴う構造・体積变化

O中村 成芳、馬場 隆之、関 安孝、城所 俊一（長岡技科大 生物系)

多くの蛋白質のフォールディング過程でモルテングロビュール (MG) 状態が過渡的な中間体として観測されている。また特定の溶液条件下 では MG 状態を平衡論的に安定な構造として観測することができ、そ の構造や安定化機構について多くの研究が行われている。シトクロム c は酸性 $\mathrm{pH}$ 、高㙁濃度下で 2 つの $\mathrm{MG}$ 状態 (MG1, MG2) が存在する ことが分光学的研究により示唆されている。我々は示差走查熱量測定 (DSC)により高塩濃度、酸性 $\mathrm{pH}$ で $2 つ の \mathrm{MG}$ 状態間の熱転移を観測 し、MG 状態の熱転移に伴う鶖力学量変化を決定した。また $M G$ 状 愁の第転移におけるCD スペクトルの温度依存性を測定し、DSCに より決定した熱力学量を用いて解析することで、MG1、MG2 の CD スペクトルの同定に成功した。その結果、MG1、MG2 ともに 2 次構 造含量は天然 (N) 状態と同程度だが、芳香族残基、一么周辺の立体構 造は N 状態とは異なることがわかった。また、MG2では MG1に比 べて 3 次構造がより壊れていることも示唆された。さらに、圧力摄動 熱量測定 (PPC) と高精度密度測定を用いて $M G$ 状態の熱転移に伴う 部分分子体皘変化を観測した。この結果、 $\mathrm{MG} 2 \rightarrow \mathrm{MGl} \rightarrow \mathrm{N}$ の転移 過程では段階的に部分分子体積が減少することが明確になった。疎水 性残基の側鎖が脱水和すると部分分子体掼が減少することを考慮す ると、シトクロムcのフォールディング過程 $(\mathrm{MG} 2 \rightarrow \mathrm{MG} 1 \rightarrow \mathrm{N})$ で は、 $\alpha$ ヘリックスが形成された後、疎水性側鎖が分子内部に段階的に 埋もれていくことが推定された。

S. Nakamura, T. Baba, Y. Seki, S. Kidokoro: The structure and volume change on the multi-state thermal transition of the moltenglobule state of cytochrome $c$

\section{$1 \mathrm{P092}$}

\author{
プロリン残基を含まないスタフィロコッカル・ヌクレ \\ アーゼ変異体の NMR シグナルの帰属と天然条件下 \\ での水素・重水素交換法 \\ ○槙 互介、遠藤 峻彦、桑島 邦博（東大・院理・物理）
}

スタフィロコッカル・ヌクレアーゼ（SNase; 149残基）のプロリン残基 を全て他の残基に置換した proline-free変異体は、野生型と比べてより 単純なフォールディングを示すことが知られており、フォールディング 速度論の研究において有用である。本研究では、proline-free SNaseの 一つである SNase P11A/P31A/P42A/P47T/P56A/P117G 用いて、 proline-free SNaseのフォールディング及び中間体の詳細を明らかにす ることを目的とする。現在まで proline-free SNase のフォールディン グ機構について、残基レベルでの詳細については知られていない。そ こで我々は、まず proline-free SNaseの多次元 NMR スペクトルを測定 した $\left(25^{\circ} \mathrm{C}, \mathrm{pH} * 7.0\right) 。{ }^{1} \mathrm{H}-{ }^{15} \mathrm{~N}$ HSQC, HNCACB 及び CBCA(CO)NH スペクトルを測定することにより、主鎖の ${ }^{1} \mathrm{H}^{N},{ }^{13} \mathrm{C} \alpha,{ }^{13} \mathrm{C} \beta,{ }^{15} \mathrm{~N}$ の シダナルの $70 \%$ 程度を㷌属することができた。㦅属されたシグナル を野生型と比較すると、置換した残基からのシグナルが存在すること 以外に殆ど差はなかった。この結果に基つき、proline-free SNaseの 安定性を残基レベルで調べるために、天然条件下において水素・重水 素交換を行い、その交换過程を NMR を用いて測定した $\left(25^{\circ} \mathrm{C}, \mathrm{pH} *\right.$ 5.1)。各二次構造要素ごとの安定性を調べたところ、 $\beta$-strand II, III 及びVが、 $\beta$-strand I 及びIV、helix I及びII よりも安定であること が示唆された。 $\mathrm{K}$. Maki, T. Endo and K. Kuwajima : NMR resonance assignments
and native-state hydrogen/deuterium exchange of a proline-free variant of staphylococcal nuclease 